\title{
Increased sensitivity to the inhibitory effect of excess iodide on thyroid function in patients with $\beta$-thalassemia major and iron overload and the subsequent development of hypothyroidism
}

\author{
T Alexandrides, N Georgopoulos, S Yarmenitis ${ }^{1}$ and A G Vagenakis \\ Endocrine Division, Department of Medicine and ${ }^{1}$ Department of Radiology, University of Patras Medical School, Patras, Greece \\ (Correspondence should be addressed to A G Vagenakis, Department of Internal Medicine, University of Patras Medical School, Patras, Greece 26500; \\ Email:vag.inmd@med.upatras.gr)
}

\begin{abstract}
Objective: Patients with $\beta$-thalassemia frequently develop primary hypothyroidism and other endocrine disorders due to iron overload. We studied whether administration of excess iodide to patients with apparently normal thyroid function could uncover an underlying thyroid disease.

Design and methods: Twenty-five patients, 10 prepubertal (mean age $11 \pm 3$ years) and 15 adults (mean age $23 \pm 5$ years) with normal thyroid hormone and TSH levels, a normal response of TSH to TRH and negative thyroid peroxidase antibodies received $20 \mathrm{mg}$ iodide three times daily for three weeks, and thyroid hormone and TSH levels were measured weekly during, and for three weeks after, iodide administration and every 3 months thereafter for the next 5 years.

Results: During iodide administration there was a significant decrease in thyroid hormone concentrations which remained within normal levels, and a significant increase in TSH concentrations which in 14 out of 25 (56\%) patients reached the hypothyroid level. Baseline TSH values were higher in those patients who developed subclinical hypothyroidism $(2.31 \pm 0.71 \mathrm{mU} / \mathrm{l}$ vs $1.34 \pm 0.64 \mathrm{mU} / \mathrm{l}$, $P=0.0016)$. Subclinical hypothyroidism developed in $70 \%$ of prepubertal and in $47 \%$ of adult patients. Serum ferritin was elevated in all patients. Nine of the fourteen patients $(64.3 \%)$ who developed subclinical hypothyroidism during iodide administration developed hypothyroidism during the 5-year follow-up compared with only one of the eleven patients with a normal response to iodide $(P=0.004)$

Conclusions: Patients with $\beta$-thalassemia should not be exposed to excess iodide due to increased sensitivity to its inhibitory effects on thyroid function. The susceptible individuals frequently develop permanent hypothyroidism in the following years.
\end{abstract}

European Journal of Endocrinology 143 319-325

\section{Introduction}

The $\beta$-thalassemias are widespread throughout the Mediterranean region, Africa and Asia. Estimates of gene frequencies range from 3 to $10 \%$ in some areas (1). Patients with $\beta$-thalassemia major frequently develop endocrine disorders, and iron overload is considered as the most important contributing factor $(2-4)$. The incidence of thyroid disorders varies greatly in different studies (5-7). Primary hypothyroidism, more often compensated, varies from $10-50 \%$ depending on the design of the study, the age and the selection of the patients, the country of origin, the type of treatment and the time of follow-up for the hematological disease (5-11).

The incidence of incipient hypothyroidism, as judged by an exaggerated thyrotropin (TSH) response to thyrotropin-releasing hormone (TRH) in the total population of the $200 \beta$-thalassemic patients of all ages treated in our hospital, is 35\%. The rest of the patients show normal thyroid hormone and TSH concentrations on the regular follow-up, and are considered to have normal thyroid function $(12,13)$.

It is known that the administration of excess iodide to normal individuals will transiently inhibit the iodine organification and will cause a small but significant decrease in serum concentrations of thyroxine $\left(\mathrm{T}_{4}\right)$ and tri-iodothyronine $\left(\mathrm{T}_{3}\right)$ and a small but significant compensatory increase in serum TSH. All these changes remain within the normal range. On the other hand, patients including children with an underlying thyroid dysfunction not clinically apparent, develop frank or subclinical hypothyroidism when exposed to pharmacological doses of iodide (14-20). The latter group of 
patients may eventually develop frank hypothyroidism in subsequent years after the iodide withdrawal (21). Two patients with $\beta$-thalassemia, followed in our clinic and treated with amiodarone for cardiac arrhythmia, who developed iodide induced hypothyroidism, prompted us to evaluate the thyroidal response to iodide in patients with $\beta$-thalassemia without apparent thyroid dysfunction.

\section{Materials and methods}

Twenty-five patients (12 males and 13 females) with homozygous $\beta$-thalassemia major were divided into two groups according to their age: the prepubertal group (age: mean $11 \pm 3$ years, range: $4-14, n=10$ ) and the adult group (age: mean $23 \pm 5$ years, range: $16-42, n=15)$. All patients were clinically euthyroid and no goiter was present either by palpation or by ultrasound evaluation. Thirteen of the twenty-five patients were positive for hepatitis $\mathrm{C}(\mathrm{HCV}+)$. Seven of them had received treatment with interferon- $\alpha$ 1-2 years earlier. After routine laboratory evaluation, including measurements of serum glutamic-oxaloacetic transaminase (SGOT), serum glutamic pyruvic transaminase (SGPT), serum ferritin, hepatitis $B$ and $C$ antigens, serum $\mathrm{T}_{4}, \mathrm{~T}_{3}$, free $(\mathrm{F}) \mathrm{T}_{4}, \mathrm{FT}_{3}$ and thyroid peroxidase antibodies, the TSH and $\mathrm{T}_{3}$ responses to TRH were evaluated in all patients. The dose of TRH administered was $5 \mu \mathrm{g} / \mathrm{kg}$ body weight, i.v. (max. $200 \mu \mathrm{g})$. TSH was measured at $0,20,30,60$ and $180 \mathrm{~min}$, and $\mathrm{T}_{3}$ at 0 and $180 \mathrm{~min}$, after TRH administration. A maximum TSH response to TRH of $\leq 23 \mathrm{mU} / \mathrm{l}$ was considered normal (22), and these patients were included in the study.

Thyroid evaluation by ultrasound was carried out in the supine position with moderate extension of the neck with a machine equipped with a linear $10 \mathrm{MHz}$ high resolution transducer and a curved array $7.5 \mathrm{MHz}$ transducer. The thyroid gland was scanned at the long and short axis of each lobe. One longitudinal and two transverse diameters were recorded and the volume of each lobe was calculated by the automated installed calculation software of the machine. Thirteen prepubertal children and twenty-one adults, matched for age, sex, height and body weight, living in the same geographical area as the patients with $\beta$-thalassemia, were used as controls.

The patients received 10 drops Lugol solution $(20 \mathrm{mg}$ iodine) 3 times daily and blood was taken weekly for 3 weeks during iodide administration and for 3 weeks after iodide withdrawal for measurement of thyroid hormones and TSH. Urinary iodide was measured before and during iodide administration to ensure compliance. The photometric method (Sandell-Kolthoff reaction) developed by Dunn et al. (23) after digestion with chloric acid at $110^{\circ} \mathrm{C}$ for $1 \mathrm{~h}$ was used. During the administration of iodide, serum TSH levels were measured weekly and the iodides were discontinued if TSH was found in the hypothyroid range ( $>5 \mathrm{mU} / \mathrm{l})$. The study was carried out in May and June 1994, and the patients have been followed-up regularly until now. Informed consent was obtained from all adult patients, and for the children, from their parents.

\section{Hormone assays}

Serum $\mathrm{T}_{3}, \mathrm{~T}_{4}$ and $\mathrm{TSH}$ were measured with the Abbott semiautomatic analyzer IMX (Chicago, IL, USA). For the measurement of $\mathrm{FT}_{3}$ and $\mathrm{FT}_{4}$, the commercially available RIA kits of Diagnostic Products Corporation were used. Determination of the thyroid peroxidase antibodies was carried out with the RIA kit of B.R.A.H.M.S. Diagnostica GmbH (Berlin, Germany).

\section{Statistics}

Two-tailed Student's t-test was used for comparisons between groups with normal distribution of values, and the Mann-Whitney two-sample test was used when the distribution of values was not normal. The Wilcoxon signed rank (two-tailed) test was used to evaluate statistical significance of differences due to iodide treatment. The Fisher's exact test (two-tailed) was used to correlate the thyroidal response to iodide with the subsequent development of hypothyroidism during the five years of the follow-up. The statistical significance was put at $P<0.05$.

\section{Results}

\section{Baseline studies}

The baseline serum thyroid hormone indices and urinary iodine excretion in all patients as well as the values during and after iodide administration are shown in Table 1. All patients had normal baseline serum $\mathrm{T}_{4}, \mathrm{~T}_{3}, \mathrm{FT}_{4}, \mathrm{FT}_{3}$, TSH and were negative for thyroid peroxidase antibodies. The mean maximum TSH and $\mathrm{T}_{3}$ response $(180 \mathrm{~min})$ to $\mathrm{TRH}$ at baseline were $13.63 \pm 5.67$ (range 1.4-22.5) $\mathrm{mU} / \mathrm{l}$ and $0.60 \pm 0.25$ (range $0.1-0.8) \mathrm{ng} / \mathrm{ml}$ respectively. The mean urinary iodine excretion at baseline for the whole group was $130 \pm 76 \mu \mathrm{g} / \mathrm{g}$ creatinine, which is very similar to the iodine excretion of the population of the area of southwestern Greece where our patients live (24).

Patients with thalassemia had smaller thyroid volume, assessed by ultrasound, as compared with the age-, sex- and body weight-matched controls (prepubertal group: $3.6 \pm 1.5$ vs $6.9 \pm 2.6 \mathrm{ml}, P=0.001$; adult group: $6.7 \pm 1.8$ vs $12.5 \pm 5.0 \mathrm{ml}, P<0.001)$. The thyroid volume was also compared with that of two distinct reference populations, one being iodine sufficient (Sweden) and the other being relatively iodine deficient (Germany), and the mean standard deviation scores for the patients with thalassemia were $-0.43 \pm 1.26$ and $-1.62 \pm 0.65$ respectively $(25)$. 
Table 1 Serum thyroid hormone and TSH concentrations before, during and after iodide treatment in 25 patients with $\beta$-thalassemia. Values are means \pm S.D.

\begin{tabular}{|c|c|c|c|c|c|}
\hline Parameter & Baseline value & $P$ value & During iodide* & After iodide* & $P$ value \\
\hline $\mathrm{T}_{3}(\mathrm{ng} / \mathrm{ml})$ & $1.18 \pm 0.24$ & 0.0022 & $1.04 \pm 0.20$ & $1.42 \pm 0.30$ & 0.0003 \\
\hline $\mathrm{T}_{4}(\mu \mathrm{g} / \mathrm{dl})$ & $8.33 \pm 1.05$ & 0.0001 & $6.988 \pm 1.02$ & $8.2 \pm 1.15$ & 0.66 \\
\hline $\mathrm{FT}_{3}(\mathrm{pg} / \mathrm{ml})$ & $4.30 \pm 0.58$ & 0.0017 & $3.80 \pm 0.55$ & $4.90 \pm 0.49$ & 0.0002 \\
\hline $\mathrm{FT}_{4}(\mathrm{ng} / \mathrm{ml})$ & $1.29 \pm 0.21$ & 0.0001 & $0.98 \pm 0.17$ & $1.32 \pm 0.21$ & 0.95 \\
\hline $\mathrm{TSH}(\mathrm{mU} / \mathrm{l})$ & $1.88 \pm 0.83$ & 0.0001 & $7.78 \pm 6.23$ & $1.86 \pm 1.12$ & 1.98 \\
\hline TSH response to TRH $(\mathrm{mU} / \mathrm{l})$ & $13.63 \pm 5.67$ & & & & \\
\hline $180 \mathrm{~min}_{3}$ increase in response to $\mathrm{TRH}(\mathrm{pg} / \mathrm{ml})$ & $0.60 \pm 0.25$ & & & & \\
\hline Urinary iodine $\mu \mathrm{g} / \mathrm{g}$ creatinine & $130 \pm 76$ & 0.0001 & $>300$ & & \\
\hline
\end{tabular}

${ }^{*}$ Compared with baseline value.

Interestingly, the thyroid volume of our adult control group is the same as the volume of the 20-year-old group of the German population (25).

\section{Response to iodide}

During iodide administration the total and free serum concentration of $\mathrm{T}_{4}$ and $\mathrm{T}_{3}$ decreased significantly but remained within the normal range in all patients (Table 1). TSH was significantly increased in all patients, and in $14(56 \%)$ patients the TSH reached the hypothyroid level (range 5.9-28.7 mU/l) (Table 2).

The baseline TSH value of the patients who developed subclinical hypothyroidism during iodide treatment was $2.31 \pm 0.71 \mathrm{mU} / \mathrm{l}$ (95\% confidence interval (C.I.) 1.90 to 2.72 ) and in those with a normal response to iodide treatment it was $1.34 \pm 0.64 \mathrm{mU} / \mathrm{l}(95 \%$ C.I. 0.90 to 1.76 ) (Table 2). The difference is significant $(P=0.001)$, and there is no overlap between the $95 \%$ C.I. of the two groups. The maximum TSH value during iodide administration was positively correlated to the basal TSH $(r=0.488, P=0.01)$. This correlation was very good in those patients who remained euthyroid during iodide administration $(r=0.767$ $P=0.0004$ ) but was not significant in those who became hypothyroid $(r=0.1 \quad P=0.7)$. The baseline values of $\mathrm{T}_{3}, \mathrm{FT}_{3}, \mathrm{~T}_{4}$, and $\mathrm{FT}_{4}$ were similar in the two groups (Table 2).

The TSH response to TRH at baseline was higher in the group who developed compensated hypothyroidism
$(13.68 \pm 4.1 \mathrm{mU} / \mathrm{l})$ than in the group with normal response to iodide $(9.4 \pm 5.4 \mathrm{mU} / \mathrm{l})$, but the difference is only marginally significant $(P=0.059)$. One of the patients in the group with the normal response to iodide had a decreased response of TSH to TRH at baseline and became hyperthyroid during the followup period of 5 years. Exclusion of this patient from the group of patients with normal response to iodide renders the difference between the two groups not significant.

The TSH response to TRH correlated weakly with the increase in TSH during iodide treatment. This was more evident when the peak TSH value on iodide treatment was correlated with the area under the curve of TSH response to TRH at baseline $(r=0.39 P=0.05)$.

The magnitude of the decrease ( $\Delta$ difference) of $\mathrm{T}_{3}$, $\mathrm{FT}_{3}$ and $\mathrm{FT}_{4}$ during iodide treatment was similar in the two groups, those with normal response and those who developed compensated hypothyroidism. However, the $\Delta \mathrm{T}_{4}$ was greater in the latter $(0.92 \pm 0.67$ vs $1.68 \pm 0.98 \mu \mathrm{g} / \mathrm{dl}, \quad P<0.001)$. The nadir value of the thyroid hormones during iodide treatment was also similar in the two groups except for the $\mathrm{FT}_{3}$ value which was $3.55 \pm 0.48 \mathrm{pg} / \mathrm{ml}$ in the first group and $4.02 \pm 0.54 \mathrm{pg} / \mathrm{ml}$ in the second $(P<0.05)$ (Table 2).

After iodide withdrawal, serum $\mathrm{T}_{4}, \mathrm{FT}_{4}$ and $\mathrm{TSH}$ returned to pretreatment levels, but serum $\mathrm{T}_{3}$ and $\mathrm{FT}_{3}$ increased above baseline levels but were still in the euthyroid range (Table 1).

Table 2 TSH and thyroid hormone levels at baseline and during iodide treatment, grouped according to the TSH response to excess iodide. Values are means \pm S.D.

\begin{tabular}{|c|c|c|c|c|c|c|}
\hline \multirow[b]{2}{*}{ Hormone } & \multicolumn{3}{|c|}{ Normal $(n=11)$} & \multicolumn{3}{|c|}{ Hypothyroid ( $n=14$ ) } \\
\hline & Baseline & On iodide & $\Delta$ & Baseline & On iodide & $\Delta$ \\
\hline $\begin{array}{l}\mathrm{T}_{3}(\mathrm{ng} / \mathrm{ml}) \\
\mathrm{FT}_{3}(\mathrm{pg} / \mathrm{l}) \\
\mathrm{T}_{4}(\mu \mathrm{g} / \mathrm{dl}) \\
\mathrm{FT}_{4}(\mathrm{ng} / \mathrm{ml}) \\
\mathrm{TSH}(\mathrm{mU} / \mathrm{l}) \\
\mathrm{TSH} \text { response to } \mathrm{TRH}(\mathrm{mU} / \mathrm{l})\end{array}$ & $\begin{array}{l}1.18 \pm 0.24 \\
4.30 \pm 0.58 \\
8.33 \pm 1.05 \\
1.29 \pm 0.21 \\
1.34 \pm 0.65 \\
9.4 \pm 5.4\end{array}$ & $\begin{array}{r}1.0 \pm 0.21 \\
3.55 \pm 0.48 \\
7.32 \pm 0.73 \\
1.03 \pm 0.16 \\
3.35 \pm 1.25\end{array}$ & $\begin{array}{l}0.12 \pm 0.16 \\
0.55 \pm 0.53 \\
0.92 \pm 0.67 \\
0.26 \pm 0.14 \\
2.02 \pm 0.76\end{array}$ & $\begin{array}{c}1.27 \pm 0.22 \\
4.46 \pm 0.66 \\
8.53 \pm 1.32 \\
1.26 \pm 0.18 \\
2.31 \pm 0.71^{\#} \\
13.68 \pm 4.10\end{array}$ & $\begin{array}{c}1.08 \pm 0.19 \\
4.02 \pm 0.54^{*} \\
6.69 \pm 1.17 \\
0.94 \pm 0.17 \\
11.26 \pm 6.38^{+}\end{array}$ & $\begin{array}{l}0.16 \pm 0.17 \\
0.43 \pm 0.59 \\
1.68 \pm 0.98^{\#} \\
0.35 \pm 0.20 \\
8.94 \pm 6.36^{+}\end{array}$ \\
\hline
\end{tabular}

${ }^{*} P<0.05,{ }^{+} P<0.01,{ }^{\#} P<0.001$ compared with normal group. 


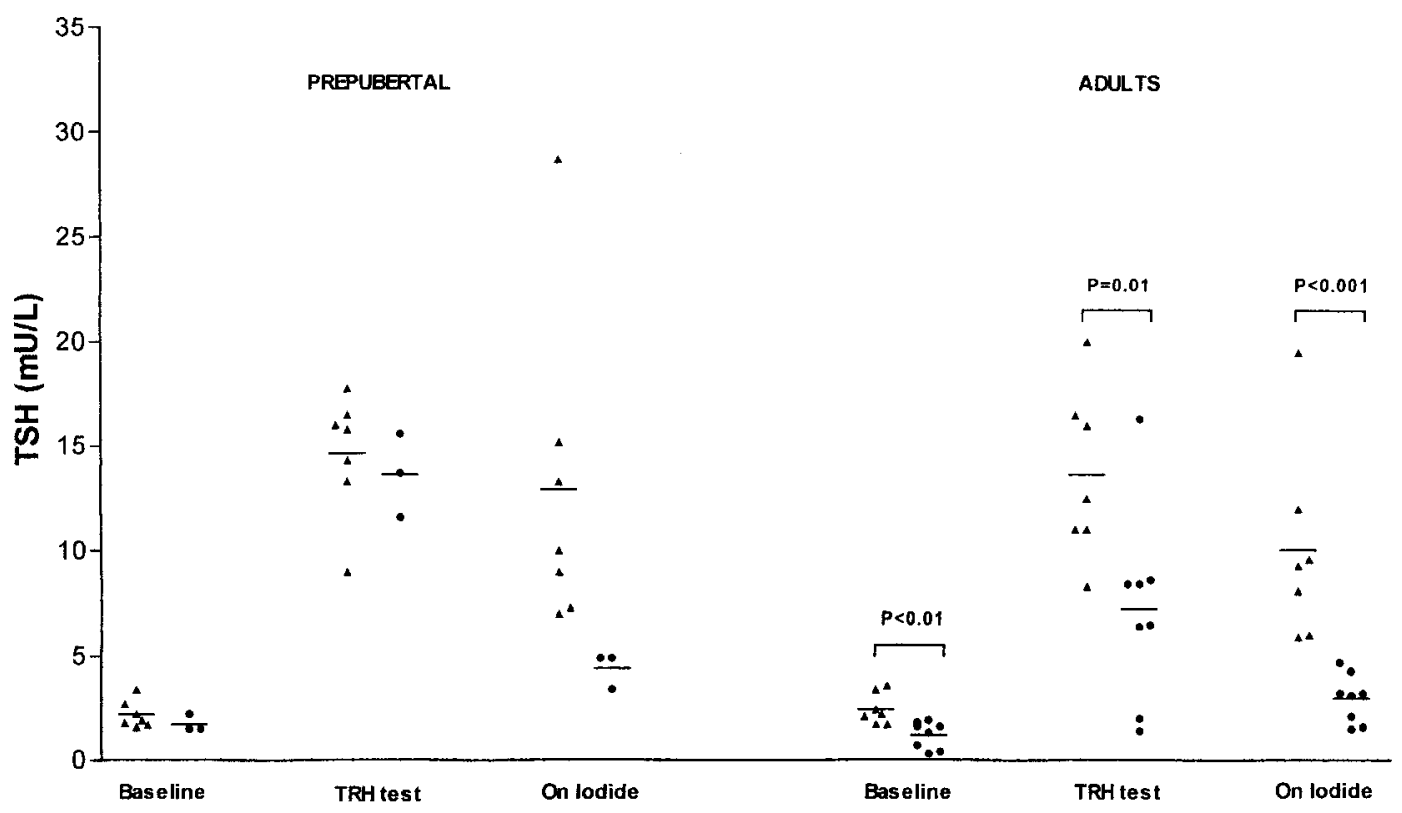

Figure 1 Baseline TSH concentrations, TSH response to TRH and peak TSH values during iodide administration in prepubertal (left) and adult (right) patients who remained normal $(\bullet)$ or developed subclinical hypothyroidism (O) during iodide treatment. Horizontal lines represent the mean value.

When the two age groups were analyzed separately, some important differences were found. Seven out of ten subjects in the prepubertal group (Fig. 1) developed subclinical hypothyroidism during iodide administration (mean serum TSH: 12.9 \pm 7.0 , range: $7-28.7 \mathrm{mU} / \mathrm{l})$, an incidence of $70 \%$. In the adult group (Fig. 1), 7 out of 15 developed subclinical hypothyroidism (mean serum TSH: $10.1 \pm 4.3$, range: $5.9-19.5 \mathrm{mU} / \mathrm{l}$ ), an incidence of $47 \%$. Baseline TSH values $(2.4 \pm 0.7$ vs $1.2 \pm 0.6 \mathrm{mU} / \mathrm{l}, P<0.01)$ and TSH response to the TRH test at baseline $(13.6 \pm 3.7$ vs $7.3 \pm 4.3 \mathrm{mU} / \mathrm{l}, P=0.01$ ) were significantly higher in the adults who developed subclinical hypothyroidism during iodide administration compared with those who did not (Table 2).

Urinary iodine excretion was measured during iodide administration and was found at very high levels to levels over the detection limit of the employed method. There was a significant difference in baseline urinary iodine excretion between those patients who developed subclinical hypothyroidism during iodide administration and those who did not $(103 \pm 69$ vs $166 \pm 69 \mu \mathrm{g} / \mathrm{g}$ creatinine, $P=0.026)$. No correlation was found between the TSH increase during iodide treatment and the $\mathrm{T}_{3}$ response to TRH at baseline or the thyroid volume.

\section{Serum ferritin and liver status}

All patients had elevated serum ferritin levels. In the patients who developed subclinical hypothyroidism, the serum ferritin concentration was $2234 \pm$ $1045 \mu \mathrm{g} / \mathrm{l}$ and in those who remained normal it was $2518 \pm 1629 \mu \mathrm{g} / \mathrm{l}$. These values represent the mean of repeated measurements of ferritin during the last two years. The mean serum liver enzyme levels for the last two years were slightly elevated in all patients. Thirteen of the twenty-five patients were HCV+. Seven out the thirteen patients developed subclinical hypothyroidism during iodide treatment and six did not. Twelve patients were HCV negative (HCV-) and seven developed subclinical hypothyroidism during iodide. Seven of the $\mathrm{HCV}+$ patients had received treatment with interferon$\alpha$ 1-2 years earlier. Four belonged to the group who developed subclinical hypothyroidism on iodide treatment and three to the group with a normal response to iodide.

\section{Follow-up}

All patients have been followed-up regularly until the present time. So far, nine of the fourteen patients (64.3\%) who developed subclinical hypothyroidism during iodide treatment have developed permanent hypothyroidism, as evidenced by distinct increases in serum TSH over $5 \mathrm{mU} / \mathrm{l}$ in four of them and over $10 \mathrm{mU} / \mathrm{l}$ in five. In the group with a normal response to iodide, 9/11 have remained normal so far, one has developed permanent hypothyroidism and another hyperthyroidism $(P=0.004$, odds ratio 22.5$)$. When the seven $\mathrm{HCV}+$ patients who had been treated in the past with interferon- $\alpha$ were analyzed, we found that 
2/7 have developed overt hypothyroidism and 5/7 have remained euthyroid. So far, none of the patients has developed thyroid peroxidase antibodies.

\section{Discussion}

The incidence of overt and subclinical hypothyroidism in $\beta$-thalassemia was reported to be relatively high especially in patients with long standing $\beta$-thalassemia. The present work clearly demonstrates that an underlying thyroid defect is present in thalassemia, even in patients without an apparent thyroid abnormality. When these patients were exposed to pharmacological doses of iodide, a great proportion were able to escape the inhibitory effects of iodide only by a substantial increase in serum TSH concentration, reaching values seen in primary hypothyroidism. When the iodides were withdrawn, all indices of thyroid function returned to baseline, as has been observed in other patients reported to develop transient hypothyroidism when exposed to pharmacological doses of iodide (1418). The majority of them developed frank hypothyroidism during the 5-year follow-up, suggesting that an underlying defect of thyroid function was present in most of them.

The cause of iodide-induced thyroid dysfunction in these patients is not readily apparent. It has been proposed that iron overload, chronic anemia, and tissue damage by hypoxia may be detrimental to thyroid tissue (26). In one report, iron deposits were found in 37\% of the patients who died from $\beta$-thalassemia (13), but the true incidence is not known. Although there is no correlation between thyroid dysfunction and serum ferritin, considerable iron overload was present despite chelation therapy with desferioxamine, and this may have led to thyroidal tissue damage. This possibility is strengthened by the finding, in the present study, of a small thyroid volume and high ferritin levels in the presence of iodine deficiency, which suggest some degree of thyroid destruction.

Cytokines, and especially interleukin-6, which has been reported to be produced into the thyroid gland by the thyroid epithelial cells and has various effects on thyroid function in vitro and in vivo (27), are potential candidates. Increased serum levels of interleukin-6 have been observed in $\beta$-thalassemia ( $\mathrm{T}$ Alexandrides, $\mathrm{P}$ Matsuka \& A Vagenakis, unpublished observations). However, patients with the euthyroid sick syndrome are not susceptible to the inhibitory effects of iodide despite the fact that serum cytokines are increased in the majority of these patients $(28,29)$.

Interferon- $\alpha$ is known to affect thyroid function and many patients who developed thyroid dysfunction during interferon- $\alpha$ treatment became hypothyroid when exposed to excess iodide (20). However, no increased sensitivity to the inhibitory effects of iodide was observed in our patients with HCV infection treated with interferon- $\alpha$.
It is interesting to note that the younger group was more sensitive to the inhibitory effects of iodide, and that these patients were in good general condition with compliance to desferioxamine (DFO) chelation therapy, and they maintained minimum hemoglobin levels above $9 \mathrm{~g} / \mathrm{dl}$. Hence, if the iron deposition had been the only causative factor, the adult group would have been more susceptible to the inhibitory effects of iodide, since a systematic detoxification program with DFO was not available before 1980 in western Greece. The greater sensitivity of the younger group cannot be attributed to the thyroid iron overload or hypoxia only. Other causes which make these patients more sensitive to the inhibitory effects of iodide and subsequently more prone to develop subclinical hypothyroidism while on iodides must therefore be sought.

There are some other points that need to be emphasized. The patients who developed subclinical hypothyroidism during iodide treatment had significantly higher basal TSH values and TSH responses to TRH compared with those who did not. It appears that these patients probably harbor an underlying thyroid defect, which became more pronounced during iodide administration. An iodide-perchlorate discharge test might have revealed an organification defect in these patients. Although the sensitivity of the thyroid to the inhibitory effects of iodide in normal children is not known, it seems unlikely that an incidence of $70 \%$ of subclinical hypothyroidism would be encountered in normal children. It has been reported that a $20 \%$ incidence of hypothyroidism was encountered in children receiving amiodarone therapy for cardiac arrhythmia, an incidence far lower from that observed in our study (30). Moreover, none of the twelve young normal adults who received iodides for a prolonged time in our laboratory, has developed transient or permanent hypothyroidism 8 years after the exposure to iodides (31). It must be pointed out, however, that the dose of iodides administered to our patients was standard in both groups. Therefore, the prepubertal patients received more iodide per kg body weight compared with the adults. Whether this would explain the higher incidence of thyroid dysfunction in these patients is not known.

Whatever the cause of increased sensitivity of the thyroid to the inhibitory effects of iodide might be, patients with $\beta$-thalassemia must be added to the long list of subjects in whom iodides should be administered with caution. The development of subclinical hypothyroidism during excess iodide exposure has a very strong prognostic value for the future development of overt hypothyroidism. This is in accordance with the concept that those patients who overcome the inhibitory effects of excess iodide with a supraphysiological increase in TSH, have an underlying thyroid defect which will become apparent in the following years.

Patients with thalassemia major commonly present with heart failure and cardiac arrhythmia. Induction 
of subclinical hypothyroidism with the administration of iodide-containing drugs, such as the antiarrhythmic amiodarone, can be detrimental and these children should be treated with $\mathrm{T}_{4}$ while on amiodarone. Consonant with our findings is the recent retrospective study by Mariotti et al. (32). They report an incidence of overt hypothyroidism of $22.7 \%$ and subclinical hypothyroidism of $18 \%$ in $\beta$-thalassemic patients treated with amiodarone. The induction of subclinical hypothyroidism in prepubertal children with thalassemia may enhance their growth retardation together with the accompanying growth hormone secretory dysfunction and the delay in puberty.

\section{Acknowledgements}

This work was presented in abstract form at the 97th Annual Meeting of the Endocrine Society, Washington DC, USA, June 14-17 1995 and in part in Thyroid and Trace Elements, 6th Thyroid Symposium, GrazEggenberg, Austria, May 8-11 1996.

\section{References}

1 Olivieri NF. The $\beta$-thalassemias. New England Journal of Medicine 1999341 99-109.

2 McIntosh N. Endocrinopathy in thalassemia major. Archives of Disease in Childhood 197651 195-201.

3 Costin G, Cogut MD, Hyman CB \& Ortega JA. Endocrine abnormalities in thalassemia major. American Journal of Disease in Childhood 1979133 497-502.

4 Petrou G, Makri M, Armoni A, Spiliotis BE \& Alexandrides TK. $\beta$-cell glucose non sensing in patients with thalassemia major and glucose intolerance. In Endocrine Disorders in Thalassemia, pp 157-160. Eds S Ando \& C Brancati. Heidelberg: Springer Verlag, 1995.

5 Italian Working Group on Endocrine Complications in Nonendocrine Diseases. Multicentre study on prevalence of endocrine complications in thalassemia major. Clinical Endocrinology 1995 $42581-586$.

6 Landau H, Matoth I, Landau-Cordova Z, Goldfarb A, Rachmilewitz EA \& Glaser B. Cross-sectional and longitudinal study of the pituitary-thyroid axis in patients with thalassemia major. Clinical Endocrinology 199338 55-61.

7 Grundy RG, Woods KA, Savage MO \& Evans JP. Relationship of endocrinopathy to iron chelation status in young patients with thalassemia major. Archives of Disease in Childhood 199471 128-132.

8 Oertel KE, Kamp GA, Munson PJ, Nienhuis AW, Cassorla FG \& Manasco PK. Multiple hormone deficiencies in children with hemochromatosis. Journal of Clinical Endocrinology and Metabolism $199376357-361$.

9 Perignon F, Brauner R, Souberbielle JC, de Montalembert M \& Girot R. Croissance et fonction endocrine dans la thalassemie majeure. Archives de Pediatrie 199350 657-663.

10 Tutar HE, Ocal G, Akar N \& Arcasoy A. Pituitary thyroid function in children with $\beta$-thalassemia major. In Endocrine Disorders in Thalassemia, pp 121-124. Eds S Ando \& C Brancati. Heidelberg: Springer Verlag, 1995.

11 Phenekos K, Karamerou A, Pipis P, Constantoulakis M, Lasaridis J, Detsi S \& Politou K. Thyroid function in patients with homozygous $\beta$-thalassemia. Clinical Endocrinology 198420 445-450.

12 Alexandrides TK, Petrou G, Pagonis S, Karahaliou F, Chryssis D,
Beratis N \& Matsouka P. Incidence of endocrine disorders in patients with thalassemia major in South-Western Greece. International Mediterranean Conference on Endocrine Disorders in Thalassemia. Universita della Calabria, May 1992. Abstract no. 35.

13 Sonacul D. Endocrine pathology in thalassemia. In Endocrine Disorders in Thalassemia, pp 75-82. Eds S Ando \& C Brancati. Heidelberg: Springer Verlag, 1995.

14 Azizi F, Bentley D, Vagenakis A, Portnay G, Bush JE, Shwachman H, Ingbar SH \& Braverman LE. Abnormal thyroid function and response to iodides in patients with cystic fibrosis. Transactions of the Association of American Physicians 197487 111-119.

15 Roti E \& Vagenakis A. Effect of excess iodide: clinical aspects. In The Thyroid, edn 7, ch 24, pp 316-327. Eds LE Braverman \& RD Utiger. Philadelphia: Lippincott, 1991.

16 Roti E, Minelli R, Gardini E, Bianconi L \& Braverman LE. Iodineinduced hypothyroidism in euthyroid subjects with a previous episode of subacute thyroiditis. Journal of Clinical Endocrinology and Metabolism $1990701581-1585$.

17 Roti E, Minelli R, Gardini E, Bianconi L, Neri T, Gavaruzzi G, Ugolotti G, Salvo D \& Braverman LE. Impaired intrathyroidal iodine organification and iodine-induced hypothyroidism in euthyroid women with a previous episode of postpartum thyroiditis. Journal of Clinical Endocrinology and Metabolism 1991 73 958-963.

18 Roti E, Minelli R, Gardini E, Bianconi L, Gavaruzzi G, Ugolotti G, Neri T, Salvo D \& Braverman LE. Iodine-induced subclinical hypothyroidism in euthyroid subjects with a previous episode of amiodarone-induced thyrotoxicosis. Journal of Clinical Endocrinology and Metabolism 199275 1273-1277.

19 Roti E, Gardini E, Minelli R, Bianconi L, Salvi M, Gavaruzzi G \& Braverman LE. Effects of chronic iodine administration on thyroid status in euthyroid subjects previously treated with antithyroid drugs for Graves' hyperthyroidism. Journal of Clinical Endocrinology and Metabolism 199376 928-932.

20 Minelli R, Braverman LE, Giuberti T, Schianchi C, Gardini E, Salvi M, Flaccadori F, Ugolotti G \& Roti E. Effects of excess iodine administration on thyroid function in euthyroid patients with a previous episode of thyroid dysfunction induced by interferon-alpha treatment. Clinical Endocrinology 199747 357-361.

21 Braverman LE, Vagenakis AG, Wang CA, Maloof F \& Ingbar SH. Studies on the pathogenesis of iodide myxedema. Transactions of the Association of American Physicians 197184 130-138.

22 Toft AD. Thyrotropin: assay, secretory physiology and testing of regulation. In The Thyroid, edn 6, ch 13, pp 287-305. Eds LE Braverman \& RD Utiger. Philadelphia: Lippincott, 1991.

23 Dunn JT, Grutchfiled HE, Gutekunst R \& Dunn AD. Two simple methods for measuring iodine in urine. Thyroid 19933 110-123.

24 Markou K, Michalaki M, Makri M, Georgopoulos N, Pagoni C, Sorras K, Alexandrides T, Kyriazopoulou V \& Vagenakis AG. Iodine intake and thyroid function in villagers and city dwellers in Southwestern Greece. 69th Meeting of the American Thyroid Association, San Diego, California. November 31996.

$25 \mathrm{Neu} \mathrm{A.} \mathrm{Sonographic} \mathrm{size} \mathrm{of} \mathrm{endocrine} \mathrm{tissue.} \mathrm{In} \mathrm{Functional}$ Endocrinologic Diagnostics in Children and Adolescents, pp 21-36. Ed MB Ranke. Mannheim: J and J Verlang, 1992.

26 Masala M, Meloni T, Gallisai E, Alagna S, Rovasio PP, Rassu S \& Milia AF. Endocrine functioning in multitransfused prepubertal patients with homozygous $\beta$-thalassemia. Journal of Clinical Endocrinology and Metabolism 19845 667-670.

27 Bartalena L, Brogioni S, Grasso L \& Martino E. Interleukin-6 and the thyroid. European Journal of Endocrinology 1995132 386-393.

28 Gardner DF, Mars DR, Thomas RG, Bumrungsup C \& Misbin RI. Iodide retention and thyroid dysfunction in patients with hemodialysis and continuous ambulatory peritoneal dialysis. American Journal of Kidney Disease $19867471-475$. 
29 Maturlo SJ, Rosenbaum RL, Pan C \& Surks MI. Variable thyrotropin response to thyrotropin-releasing hormone after small decreases in plasma free thyroid hormone concentrations in patients with non thyroidal diseases. Journal of Clinical Investigation 198066 451-456.

30 Costigan DC, Holland FJ, Daneman D, Vogel M \& Ellis G. Amiodarone therapy effects on childhood thyroid function. Pediatrics 198677 703-708.

31 Markou K, Makri M, Heliopoulos A, Alexandrides TK \& Vagenakis AG. Thyroid hormone secretion following discontinuation of large quantities of iodides in normal individuals. Ninth
International Congress of Endocrinology. Nice, August 30-September 5 1992, pp 305. Abstract no. P-05.01.120.

32 Mariotti S, Loveselli A, Murenu S, Sau F, Valentino L, Mandas A, Vacquer S, Martino E, Balestrieri A \& Lai ME. High prevalence of thyroid dysfunction in adult patients with beta-thalassemia major submitted to amiodarone treatment. Journal of Endocrinological Investigation 199922 55-63.

Received 9 December 1999

Accepted 9 May 2000 